\title{
KADAR MDA DAN RASIO GSH/GSSH PADA KEHAMILAN NORMAL, PREEKLAMPSIA BERAT DAN EKLAMPSIA DI MALANG
}

\section{THE LEVEL OF MDA AND THE GSH/GSSH RATIO IN NORMAL PREGNANCY, HEAVY PREECLAMPSIA AND ECLAMPSIA AT MALANG}

\author{
Siti Candra*, M Aris Widodo*, Soetomo Suwarto*, I Ketut Muliartha G** \\ * Laboratorium Farmakologi Fakultas Kedokteran Universitas Brawijaya Malang \\ ** Laboratorium Obstetri \& Ginekologi Fakultas Kedokteran Universitas Brawijaya / RSU dr. Saiful Anwar Malang \\ *** Laboratorium Biomedik Fakultas Kedokteran Universitas Brawijaya Malang
}

\begin{abstract}
Preeclampsia is marked by vasospasme, increasing peripheral vascular resistance and permeability, endothelial cell and reducing organ perfusion. It occurs because of the increasing of lipid hydroperoxides. The uncontrolled production of lipid hydroperoxides causes oxidative stress and destroys cell integrity. Oxidative stress condition express the increasing oxidant and decreasing antioxidant. One of the antioxidant is GSH that is used to neutralize the increasing of Malondialdehyde (MDA) level. The objective of this study was to see the difference of MDA content and GSH. GSSG ratio between the normal pregnancy, preeclamsia and eclampsia. This study was cross sectional study. The samples were 36 blood plasma consisted of 12 normal pregnancy, 12 preeclampsia and 12 eclampsia before birth. The blood plasma, was measured for its MDA level and the GSH/GSSH ratio. The result showed that the level of MDA of plasma in preeclamptic and eclamptic pregnancy were higher than normal pregnancy $p=0.000$, due to lipid peroxidation resulted from increased production of lipid hydroperoxides on preeclamptic and eclamptic pregnancy. The average of GSH/GSSH ratio in normal pregnancy is higher than preeclamptic and eclamptic plasma $p=0.001$. Decreasing the GSH/GSSH ratio might be caused by the use of GSH in neutralizing the increase of lipid hydroperoxides. There is a decrease of GSH/GSSH ratio in preeclamptic and eclamptic plasma that is used to neutralize the increasing of Malondialdehyde (MDA) content.
\end{abstract}

Key words: preeklamptic, MDA, GSH/GSSH ratio.

\section{PENDAHULUAN}

Preeklampsia (PE) merupakan sindroma spesifik pada kehamilan manusia yang sebelumnya sehat. Gejala ini ditandai dengan peningkatan tekanan darah dan adanya proteinuri setelah kehamilan 20 minggu. Angka kejadian PE berkisar antara $7-10 \%$ dari seluruh kehamilan dengan manifestasi klinis berbeda - beda mulai yang ringan sampai menimbulkan kematian. Preeklampsia merupakan penyakit yang mengancam kehidupan baik pada ibu dan janin (1).

Gambaran yang terjadi pada PE ditandai adanya vasospasme, peningkatan resistensi vaskuler perifer, peningkatan permiabilitas sel endotel serta juga terjadi pengurangan perfusi organ. Hal tersebut menimbulkan sindroma yang bersifat polymorphik yang hampir setiap organ dipengaruhi (2). Pada Eklampsia didapatkan adanya iskemia serebral, edema kortek dan subkortek, bercak perdarahan dan infark yang diakibatkan oleh vasokontriksi (3).

Etiologi PE berhubungan dengan perubahan fisiologis arteri spiralis uterina yang tidak adekuat. Invasi trophoblas ke arteri spiralis maternal yang tidak adekuat berperan

Jurnal Kedokteran Brawijaya,Vol. XXIII, No. 1, April 2007 Korespondensi: Siti Candra; Laboratorium Farmakologi FK Unibraw; Jl. Veteran Malang; Telp. 0341-580993 ext. 110 penting dalam terjadinya PE dan merupakan kunci terjadinya perubahan dari keadaan arteri spiralis uterina (4). Hal ini menyebabkan peningkatan oksigenasi secara cepat dalam jaringan plasenta dan fluktuasi tekanan oksigen ini merupakan dasar dari terjadinya kelainan iskemia-reperfusi. Keadaan ini akan menghasilkan vasoaktive yang akan ditranfer ke sirkulasi maternal. Vasoaktive yang masuk ke sirkulasi maternal menyebabkan disfungsi endotel maternal. Disfungsi endotel menonjol pada penderita PE dan merupakan patogenesa yang berperan penting pada preeklampsia (5)

Kelainan iskemia-reperfusi sekarang dikenal baik sebagai penyebab malperfusi dari beberapa sistem organ dan diperantarai terutama melalui generasi Spesies Oksigen Reaktif. Jika generasi Spesies Oksigen Reaktif melebihi kapasitas dari pertahanan antioksidan akan menghasilkan stress oxidative yang akan merusak lipid, protein dan DNA. Salah satu marker dari stress oxidative pada preeklampsia adalah peningkatan lipid peroksida yang bisa diukur dari kadar Malondialdehyde (MDA) $(6,7)$.

Spesies oksigen reaktif menyebabkan penurunan antioksidan dalam sel. Pada kehamilan dengan komplikasi PE kadar antioksidan glutathion (GSH) menurun. Penurunan antioksidan ini menunjukkan pemakaian meningkat dan sin- 
tesisnya terganggu. Dengan defisiensi antioksidan tersebut, wanita hamil yang mengalami PE tidak mampu mengkontrol akibat peningkatan stress oksidative yang berpotensi meningkatkan kerusakan sel endotel pembuluh darah (8).

Tujuan penelitian ini mengetahui perbedaan kadar MDA sebagai oksidan dengan rasio GSH/GSSH sebagai antioksidan pada kehamilan normal, preeklamsia berat dan Eklampsia.

\section{METODE}

Rancangan penelitian menggunakan cross sectional dengan mengisi lembar persetujuan. Sampel keseluruhan berjumlah 36 plasma darah, 12 sampel dari kehamilan normal, Preeklampsia berat dan Eklampsia sebelum melahirkan. Kriteria preeklampsia berdasarkan peningkatan tekanan darah setelah kehamilan 20 minggu dan adanya proteinuri. Preeklampsia berat bila tekanan darah $\geq 160 / 110$ $\mathrm{mmHg}$ dengan proteinuri positif $\geq 3$. Sedangkan Eklampsia bila penderita PEB disertai kejang. Sampel diambil dari Rumah sakit Saiful Anwar dan RS sakit swasta yang ada di Malang. Pengambilan sampel darah menggunakan tabung yang mengandung heparin untuk mengambil plasmanya. Pengambilan plasma untuk menghindari faktor yang pengganggu dari lepasnya produk yang masuk ke serum selama proses koagulasi (9). Penderita juga diambil urinnya untuk pemeriksaan proteinuri.

Sampel darah diambil dari vena antekubiti dan ditempatkan dalam suhu kamar selama 2 - 10 jam sebelum sentrifugasi $2000 \mathrm{~g}$ selama 20 menit dan dialiquot dalam keadaan steril dan disimpan dalam temperatur $-40^{\circ} \mathrm{C}$.
Selanjutnya plasma darah akan diukur kadar MDA dan Rasio GSH/GSSH.

Untuk mengetahui apakah terdapat perbedaan kadar MDA, rasio GSH/GSSH pada plasma kehamilan normal, Preeklampsia berat dan eklampsia, digunakan uji beda One Way Anova dengan tingkat kepercayaan 95\%, kemudian untuk mengetahui kehamilan yang menunjukkan perbedaan ditunjukkan dengan uji perbandingan berganda Tukey dengan tingkat kepercayaan $95 \%$.

\section{Pemeriksaan MDA pada plasma: (10)}

Masing-masing sampel diambil 1cc, kemudian ditambah 100uL TCA $100 \%$, ditambah 250uL HCl $1 \mathrm{~N}$ ditambah $100 \mathrm{uL}$ NaThio $1 \%$. Panaskah $100^{\circ} \mathrm{C}$ selama 20 menit. Selanjutnya dibaca dengan spectrofometer pada panjang gelombang $532 \mathrm{~nm}$

\section{Pemeriksaan GSSH/GSH pada plasma: (11)}

Pipet 50uL sampel dan standart dimasukkan pada setiap sumuran, kemudian ditambahkan 100uL Reaction mixture (GSH: Mix $5 \mathrm{ml}$ of DNTB, $5 \mathrm{ml}$ of NADPH, $5.75 \mathrm{ml}$ of buffer and $0.1 \mathrm{ml}$ of $\mathrm{GSH}$ reductase; GSSH: Mix $5 \mathrm{ml}$ of DNTB, $5 \mathrm{ml}$ of NADPH, $5.75 \mathrm{ml}$ of buffer). Kemudian dibaca dengan mikroplete reader $405 \mathrm{~nm}$

\section{HASIL PENELITIAN}

\section{Kadar MDA pada Kehamilan Normal, Preeklampsia dan Eklampsia}

Gambaran rerata dan keragaman data kadar MDA plasma kehamilan normal, PE berat dan eklampsia, disajikan pada Gambar 1.

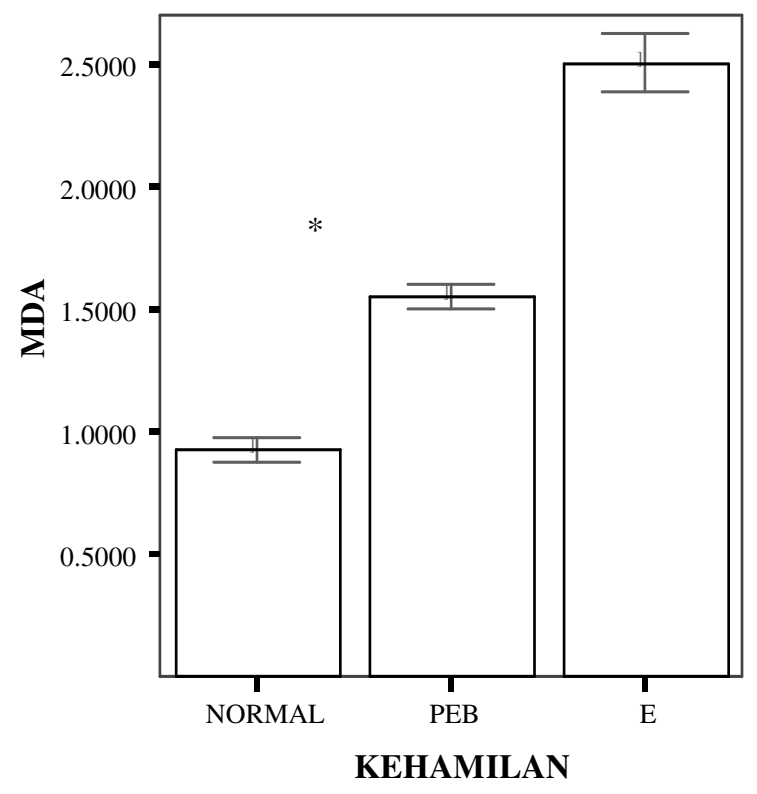

Error Bars show Mean +/- 0.6

Bars show Means

Keterangan : * $=$ signifikan $(p<0.05)$

Gambar 1. Grafik Rerata dan SD Kadar MDA pada Plasma Kehamilan Normal, PEB dan Eklampsia 


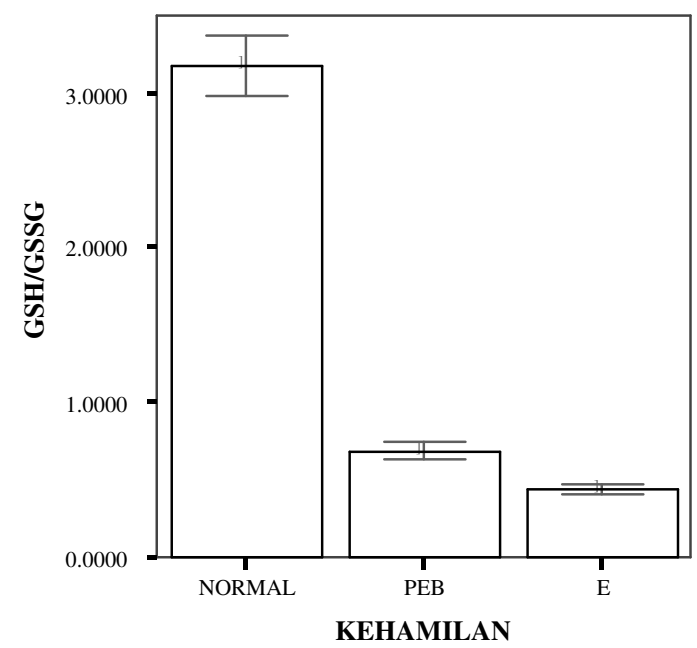

Error Bars show Mean +/- 0.6 SE

Bars show Means

Keterangan : * $=$ signifikan $(p<0.05)$

\section{Gambar 2. Grafik Rerata dan SD GSH/GSSG pada Plasma Kehamilan Normal, PEB dan Eklampsia}

Gambar 1 menunjukkan bahwa rerata kadar MDA pada plasma kehamilan N $0.930 \pm 0.088$, kehamilan PEB $1.553 \pm 0.087$, kehamilan $E 2.506 \pm 0.201$. Rata - rata kadar MDA plasma semakin meningkat dari kehamilan N, PEB dan E. Rerata kadar MDA pada plasma kehamilan PEB berbeda signifikan dengan plasma kehamilan $N(p=0.000)$ ditandai dengan bintang pada gambar batang PEB, plasma kehamilan $E$ berbeda signifikan dengan plasma kehamilan $N(p=0.000)$ ditandai dengan bintang pada gambar batang $E$, plasma kehamilan $E$ berbeda signifikan dengan plasma PEB $(p=0.003)$ ditandai dengan bintang pada gambar batang $\mathrm{E}$.

\section{Rasio GSH I GSSH pada Kehamilan Normal, Preeklampsia dan Eklampsia}

Perbedaan rasio GSH/GSSH pada plasma kehamilan normal, PE berat dan eklampsia, digambarkan pada Gambar 2. Gambar 2 menunjukkan bahwa rerata kadar rasio GSH/GSSG pada plasma kehamilan Normal $3.178 \pm 0.056$, kehamilan PEB $0.689 \pm 0.057$, kehamilan $E$ $0.439 \pm 0.046$. Rata - rata kadar GSH/GSSG plasma semakin menurun dari kehamilan N, PEB ke E. Rerata rasio GSH/GSSG pada plasma kehamilan PEB signifikan lebih rendah dibandingkan dengan plasma kehamilan $\mathrm{N}$ $(p=0.000)$ ditandai dengan bintang pada gambar batang $P E B$, plasma kehamilan $E$ signifikan lebih rendah dibandingkan dengan plasma kehamilan $N \quad(p=0.000)$ ditandai dengan bintang pada gambar batang E. Plasma kehamilan $\mathrm{E}$ berbeda signifikan dengan plasma PEB $(p=0.048)$.

\section{DISKUSI}

\section{Kadar MDA pada Kehamilan Normal, Preeklampsia dan Eklampsia}

Peroksidasi lemak adalah suatu proses normal yang terjadi dalam seluruh sel dan jaringan. Proses ini melibatkan perubahan oksidatif asam lemak tak jenuh menghasilkan produk utama yang dikenal dengan lipid peroksida. Keadaan yang dapat menstimulasi peroksida lemak adanya peningkatan radikal bebas seperti yang terjadi pada kehamilan yang mengalami preeklampsia. Lipid peroksida bila produksinya tidak terkontrol akan menyebabkan stres oksidative yang akan merusak integritas sel (12). Kadar MDA dalam plasma digunakan untuk mengestimasi kadar lipid peroksida. Pada plasma PE kadar malondialdehyde menunjukkan 4,5 lebih tinggi konsentrasinya dari pada di plasma kehamilan normal $(13,14)$.

Pada analisis data kadar MDA plasma menggunakan uji perbandingan berganda Tukey menunjukkan bahwa terdapat perbedaan yang signifikan antara kadar MDA pada plasma kehamilan normal dengan plasma PEB dan eklampsia $(p=0,000<0.05)$. Hal ini menunjukkan ada perbedaan yang nyata kadar MDA antara plasma kehamilan normal, PEB, dan eklampsia. Kadar MDA pada PEB dan eklampsia lebih tinggi dibandingkan pada plasma kehamilan normal.

Dari hasil penelitian ini menunjukkan terjadi peroksidasi lemak yang lebih besar pada ibu hamil yang mengalami preeklamsia berat dan eklampsia dari pada kehamilan normal dengan mengukur kadar MDA yang merupakan produk terjadinya peroksidasi lemak. Peroksidasi lemak meningkat pada sampel dari ibu hamil 
yang mengalami preeklampsia berat dan eklampsia menggambarkan adanya peningkatan radikal bebas yang menyerang lemak tidak jenuh.

Peningkatan lipid peroksida akan mengaktifkan siklooksigenase dan menghambat secara selektif terhadap prostasiklin sintetase menyebabkan peningkatan produksi thromboksan dan penurunan prostasiklin yang menghasilkan vasokonstriksi pembuluh darah. Rasio perubahan prostaglandin menimbulkan vasospasme dengan eksaserbasi iskemia plasenta, peningkatan lipid peroksidasi dan kerusakan sel (15).

\section{Rasio GSH I GSSH pada Kehamilan Normal, Preeklampsia dan Eklampsia}

GSH adalah suatu tripeptide ( L-glutamyl-L-cysteinylglycine) berisi kelompok sulfihidril dan suatu nukleophile yang kuat berfungsi menginaktivasi senyawa elektrophilik reaktif, melindungi sel terhadap oksidan dan sinyal transduksi. Fungsi GSH yang bersifat melindungi melibatkan proses enzimatik dan nonenzimatik. GSH adalah antioksidan yang bersifat hidrofilik scavenger ditemukan di sitosolik, mitokondrial dan nukleus (16).

Sistem reduksi oksidasi GSH adalah penting dalam memelihara homeostasis GSH intraselluler yang penting dalam proses fisiologis sellular normal. Sistem ini menggunakan GSH sebagai substrate dalam suatu reaksi yang melibatkan glutathione peroxidase (GPX) untuk detoksifikasi lipid peroksida. Reaksi ini menghasilkan GSH dioksidasi (GSSG). Secara fisiologis reaksi glutathione reduktase dikendalikan ke arah GSH dengan perbandingan GSH terhadap GSSG secara normal > 90\%. Perbandingan GSH terhadap GSSG dipertahankan tinggi untuk meminimalkan akumulasi disulfida intrasellular yang bersifat toksik. Bila ada stres oxidatifve akan mengubah perbandingan $\mathrm{GSH}$ terhadap GSSG menyebabkan terjadi pergeseran buffer reduksi oksidasi GSSG terhadap GSH. (17).

Gambar 2 menunjukkan bahwa rerata rasio GSH/GSSG pada plasma kehamilan normal lebih tinggi dibandingkan plasma PEB dan Eklampsia. Hasil uji BNT menunjukkan bahwa terdapat perbedaan yang signifikan antara rerata rasio GSH/GSSG pada plasma kehamilan normal dengan plasma PEB dan eklampsia dengan $p<0.05$.

Pada kehamilan normal didapatkan rasio GSH/GSSG lebih tinggi dari pada kehamilan dengan PEB maupun eklampsia. Hal ini memberi gambaran bahwa pada kehamilan dengan PEB atau eklampsia terjadi peningkatan radikal bebas yang akan menurunkan kadar rasio GSH/GSSG diperlukan untuk menetralisir peroksida lemak. Dengan kata lain pada PEB dan eklampsia terjadi pergeseran buffer reduksi oksidasi GSSG terhadap GSH, sehingga menurunkan kadar rasio GSH/GSSG. Penurunan rasio GSH/GSSG juga disebabkan oleh penurunan NADPH yang terjadi pada preeklampsia, yang mana NADPH berfungsi untuk mengubah GSSG ke GSH dengan bantuan enzim gluthation reduktase.

\section{KESIMPULAN}

Pada PEB dan eklampsia terjadi penurunan rasio GSH/GSSG yang digunakan untuk menetralisir kadar MDA yang meningkat.

\section{DAFTAR KEPUSTAKAAN}

1. Many A, Hubel AC, Fisher JS, et al. Invasive Cytotrophoblasts Manifest Evidence of Oxidative Stress in Preeclampsia. AM.J. Pathology 2000; 158: 321-331.

2. Hubel AC. Oxidative Stress in the Pathogenesis of Preeclampsia. EBM 1999; 222: 222-235.

3. Zeeman GG, Reckenstein LJ, Twickler MD, Cunningham GF. Cerebral Infarction in Eclampsia, American journal of Obstetric \& Ginecology. March 2004; 190 (3).

4. Jauniaux E, Adrian L, Watson, et al. Onset of Maternal Arterial Blood Flow and Placental Oxidative Stress. AM.J. Pathology 2000; 157: 2111-2122.

5. Mellembakken RJ, Aukrust P, Ueland T, et al. Chemokines and Leukosite Activation in the Fetal Circulation During Preeclampsia. Hypertension 2001; 38: 394.

6. Cunningham GF, Gant FN, Leveno JK, et al. Hipertensive Disorder in Pregnancy. Williams Obstetrics 2001; 2 1st, $587-$ 809.

7. Hung HT, Skepper NJ, Graham J. Burton JG. In Vitro Ischemia-Reperfusion Injury in Term Human Placenta as a Model for Oxidative Stress in Pathological Pregnancies. AM.J. Pathology 2001; 159: 1031-1043.

8. Beinder E, Scalera F, Schlembach D. Influence of Reduced Intracellular Glutathione Availability on the Secretion of Vasoactive Substances by Human Umbilical Vein Endothelial Cells. Hypertens Pregnancy 2001; 20(1): 45-58.

9. Baker NP, Davidge TS, Roberts MJ. Plasma from Women with Preeclampsia Increases Endothelial Cell Nitric Oxide Production. Hypertension 1995; 26: 244-248.

10. Das UN, Elis G, Begin ME, Horrobin DF. Free Radical Bio. Med 1987; $3,9$.

11. Baker. Micro-Glutathione Assay. Anal. Biochem 1990; 190: 360.

12. Litte RE, Gladen BC. Levels of Lipid Peroxides in Uncomplicated Pregnancy: A Review of the Literature. Reprod Toxicol 1998; 13 (5): $347-352$. 
13. Takacs P, Kauma WS, Sholley MM, et al. Increased Circulating Lipid Peroxides in Severe Preeclampsia Activate NF-kB and Upregulate ICAM-1 in Vascular Endothelial Cells. The FASEB Journal 2001.

14. Madazli R, Benian A, Gumustas K, Uzun H, Ocak V, Aksu F. Lipid Peroxidation and Antioksidants in Preeclampsia. Eur J Obstet Gynecol Reprod Biol 1999; 85(2): 205-208.

15. Morris JM, Gopaul NK, Endresen MJ, et al. Circulating Markers of Oxidative Stress are Raised in Normal Pregnancy and Pre-Eclampsia. Br J Obstet Gynaecol 1998; 105(11):195-199.

16. Chaudiere J, Ferrari IR. Intracellular Antioxidants: from Chemical to Biochemical Mechanisms. Food Chem Toxicol 1999; 37(9-10): 949-962.

17. Scalera F, Fischer T, Schlembach D \& Beinder E Serum from Healthy Pregnant Womwn Reduces Oxidative Stress in Human Umbilical Vein Endothelial Cells. Clinical Science 2002; 103: 53-57.

18. Klatt P \& Lamas S. Regulation of Protein Function by S-Glutathion in Response to Oxidative and Nitrosative Stress, The FEBS Journal, Eur. J. Biochem 2000; 267, 4928-4944. 